\title{
Másolási stratégiák Enyedi György prédikációinak hagyományozódásában
}

„Két ok késztetett arra, hogy ezt a beszédet, melyet múlt vasárnap, a te eltávoztod után mondottam ellened, azon melegében szóról szóra leírjam, s neked olvasásra megküldjem. Egyik az, mert hallomásom szerint a háromság megvallása miatt kedvedben járók között vannak olyanok, akik prédikációm során ott voltak a gyülekezetben, $s$ ezek azt híresztelik, hogy szerfölött keményen bántam veled. Márpedig nem akarnám, sem hogy szavaimhoz valamit hozzátoldjanak, sem hogy azokat elferdítve juttassák el hozzád. Meg aztán azt akartam, hogy ez a beszéd írásban legyen meg, hadd tudja megítélni minden józan eszű ember, vajon az én cáfolatom hamis vagy igazságtalan volt-e."

Ha nem tartjuk csupán retorikai fogásnak Enyedi e sokak által ismert, Szilvásinak írott megjegyzését híres 60. prédikációjának elején, feltételezhetjük, hogy Enyedi beszédeinek írásban készített vázlatai és szóban való előadásuk valóban megelőzte azok hosszabb, írott formáját. Ezt erősítik meg a több forrásban is felbukkanó latin nyelvü beszédvázlatok, vázlatra épített beszédek, prédikáció-kivonatok. Harminc-harminchárom beszédet tartalmazó triacasokban visszatérő beszédcsoportokat különböztethetünk meg, ilyenek az adventi és karácsonyi ünnepkörhöz kapcsolódó prédikációk, a vízkereszt ünnepköre vagy a húsvét és a pünkösd ünnepköreihez kapcsolódó beszédek. Ám nem csupán maguk a beszédek nem oszthatók vasárnaponként naptári sorrendbe, de párhuzamos beszédek esetében nem egyszer előfordul, hogy míg az egyik gyüjteményben csupán egy, más gyüjteményben egyazon szám alatt egy több részre bontott prédikációt találunk, mely jelölten nem egy alkalom során hangzott el. Mivel nyomtatott változat egyáltalán nem áll rendelkezésünkre, felértékelődik a másolók szerepe. Egy aktív, majd száz évig tartó szöveghagyományozási és szöveghasználati folyamatba pillanthatunk bele a korpusz vizsgálata során, melynek mélyebb rétegei mindezidáig nem kerültek részletes feltárásra.

Az Enyedi-prédikációk ma (forrásból vagy utalásból) ismert kéziratainak és másolatainak száma huszonegy tételt tesz ki. ${ }^{2} \mathrm{~A}$ korpusz beszédeinek beazonosítását

\footnotetext{
${ }^{1}$ KéNosi Tőzsér János, Uzoni Fosztó István, Az erdélyi unitárius egyház története, I, ford. Márkos Albert, s. a. r. Balázs Mihály, Hoffmann Gizella, Kovács Sándor, Molnár B. Lehel, Kolozsvár, Erdélyi Unitárius Egyház, 2005, 346.

${ }^{2}$ Dolgozatomban a ma is meglévő, magyar nyelvű másolatok közül fogok néhányat említeni. A cikkben szereplö, kódexekre vonatkozó adatok ismertetésekor Káldos János munkáira hivatkozom és saját kutatásaimra támaszkodom. Legutóbb a témában megjelent cikk: KáLDos János, Enyedi György prédikációinak szöveghagyománya = Érték és értelmezés, szerk. BoKa László, Sirató Ildikó, Bp., Gondolat, OSzK, 2010, 188-207. A ma is meglévő magyar nyelvű prédikációt tartalmazó kötetek a következők: K3: Lisznyai Gyárfás másolata, 1613 (Academia Română, Filiala Cluj-Napoca [A továbbiakban: Academia
} 
nem csupán az Enyedire vagy a triacasokra, beszédszámokra vonatkozó gyakori hivatkozás könnyíti meg, hanem az is, hogy a beszédek eleje azok felépítésének bemutatásával együtt, valamint a beszédek vége szinte mindig megegyezik a különböző másolatokban. Természetesen nem mindig beszélhetünk szó szerinti egyezésről, ám ha figyelmen kívül hagyjuk a különböző szóalakok használatát vagy a jelzők, szinonimák halmozását, mondhatjuk, hogy ezen részek beazonosíthatóak. Így ismeretlen, eddig feltáratlan anyagú kódexekben is segítséget kaphatunk a beszédek azonosításához, valamint egyes hibák feltárása könnyebbé válik a már ismert kötetekben.

Az első ma ismert datálható másolat 1613-ból származik, a legutolsó másolati adatunk a korszakban a 17. század végére tehető. A K1-5, valamint S sziglákkal ellátott kötetek a gyüjteménynek egy-egy összefüggő részét tartalmazzák, egész triacasokat vagy azoknak nagyobb részeit. Ezekkel a kötetekkel kapcsolatban a szerkesztési stratégiák csak részlegesen elemezhetők. Jól nyomon követhető azonban a másolói bejegyzésekből, hogy melyik kéz hogyan másolta a beszédeket, így például a meglévő mellett több triacast is lemásolt. Ezek az egyéb másolatok sajnos kivétel nélkül mára elvesztek, vagy lappanganak. Az is megesett, hogy a másoló egyes beszédeket jelölten kihagyott, mert párhuzamosan több gyüjteményt másolt, és az már más, általa összeállított - ma szintén nem ismert - kódexben megvolt. A beszédgyüjteményekben felfedezett hibák és párhuzamosságok ${ }^{4}$ emellett arra is rávilágítanak, hogy még ezek a jól szerkesztettnek

III.], MS. U. 737/III.); Gy: Gyalai Sámuel prédikációgyüjteménye, Tarcsafalva, 1617-1626 (Cluj Napoca, Biblioteca Centrala a Universitatii Victor Babes, MS. 1777.); K4: Ismeretlen másoló, Nagyajta, 1621 (Academia III., MS. U. 737/IV.); Sz: Fejérdi Gergely másolata, h. n., 1629 (Târgu Mureş, Teleki-Bolyai Könyvtár, 0439.); K1: Ismeretlen másoló, h. n., 17. század első fele (Academia III., MS. U. 737/I.); S: Ismeretlen másoló, h. n., 17. század közepe (Sárospataki Református Kollégium Nagykönyvtára, Kt. 7.); K5: Ismeretlen másoló, h. n., 17. század közepe (Academia III., MS. U. 737/V.); M: Egyházi beszédek, Sinfalva, Tordatúr (?), 1642-1650 (Târgu Mureş, Teleki-Bolyai Könyvtár, 0636.); CV: Conciones vetustissimae, 1642 előtt - 1659 (Academia III., MS. U. 262.); K2: Bitai János, Toroczkó, 1664 (Academia III., MS. U. 737/II.). A kódexeket a továbbiakban a bevett sziglákkal jelölöm.

${ }^{3}$ A beszédkezdetek és -végek ellenőrzése során került tisztázásra a K3 anyagának mai rendje is. A kötet kötése ellenére a kevésbé jó állapotú másolatok közé sorolható. A másoló, Lisznyai Gyárfás több helyen is dátumozta a beszédeket. Apróbb megjegyzésekből részben rekonstruálhatjuk, hogy mikor és hol másolták és használták a könyvet. Bár a könyv elején részletes - a másolatok között a legrészletesebb - listát kapunk textus és cím szerinti bontásban is a kódex tartalmáról, a beszédek a könyv elején zavaros sorrendben találhatók. A könyv elvileg a 37-66. számú beszédeket, vagyis a második triacast tartalmazza, de az 51. beszédig kevert sorrendben, a 60. beszéd hiányzik. A szövegek szorosabb vizsgálata során kiderült, hogy az egyes beszédekben nem csupán, vagy nem laphiányokról van szó, hanem a beszédek lapjai, lapcsomagjai össze vannak keveredve. Valószínűleg előbb másolták le őket és utána kötötték be, vagy a lapok egy része a régi kötést szétszedve került más sorrendbe. Így a 37., a 41., a 45. beszéd két részben kerül elénk, jelölés nélkül. A szövegek beazonosítását a párhuzamos másolatokat tartalmazó K4 kódex segítségével végezhetjük el. Árnyalja a képet nem csupán az, hogy az 58. beszéd jelölten kerül a sorrendben rossz helyre, és a kötet közepén korábbi dátumot találunk, mint az elején, de az is, hogy a kevert számú beszédek nem mindegyike kezdődik új lapon, így a 37. beszéd után ugyanazon a lapon kezdődik a 43. beszéd, vagy az 58. beszédet egyazon lapon követi az 50. számú prédikáció. Ez megerösíti azt, hogy a sorrend már eleve nem volt rendezett.

${ }^{4}$ Ezzel kapcsolatban két, a közelmúltban megjelent cikkre hívnám fel a figyelmet: KáLDos János, Enyedi 
tünő, az eredeti struktúrát szorosan követő kötetek is furcsaságokat mutatnak, melyeket vagy már maga az eredeti gyüjtemény is tartalmazott, vagy a másolások során bekövetkezett átszerkesztések, hiányos, kevert vagy sérült források használata során jöttek létre.

Az egységes anyagot tartalmazó köteteknél a szerkesztés szempontjából érdekesebbeknek tűnnek azok, melyekbe a korpuszból válogatva másoltak beszédeket. A legtöbb anyagot tartalmazó ilyen típusú kötet a Székelykeresztúri Kódex (Sz), mely átmeneti stádiumnak mondható az összefüggő anyagot közlő és a néhány beszédet tartalmazó kódexek között. Huszonnégy beszédet találunk benne a második triacas anyagából, tizenhárom beszédet a hatodik triacasból és két beszédet a csonka hetedik triacasból. A kötet másolója jó minőségü szövegeket ad, ám az is igaz, hogy sokszor belenyúl, kiegészít, átír, aktualizál. Egész más jellegű az M sziglát viselő Marosvásárhelyi Kódex, mely tíz Enyedi-beszédet tartalmaz, négyet az első triacasból, hármat a második triacasból, egyet valószínüsíthetően a jelenleg ismeretlen anyagú harmadik, kettőt pedig a negyedik triacasból..$^{5}$ A kódex rossz állapotban van, a beszédek maguk is vegyes színvonalúak, a szöveghagyományozódás és szövegromlás módjának és kérdésének vizsgálata azonban ebben az esetben is fontos és érdekes tanulságokkal kecsegtet. Gyalai Sámuel három Enyedi-beszédet másol le vegyes tartalmú kódexébe (Gy), a 43., ${ }^{6}$ az 50. és a 100. számút, előbbieket jelöletlenül, utóbbit jelölve.

Szintén ebbe a csoportba illik a Conciones vetustissimae (CV) címen ismert, az eddigi vélekedések szerint 1651-1659 között másolt kódex, melynek alapos leírását legutóbb Balázs Mihály végezte el. ${ }^{7}$ A kódexről feltételezhetjük, hogy egybekötötték az üres lapokat, majd több kéz másolta bele a beszédcsoportokat különböző elképzelések szerint. ${ }^{8}$ A kézirat - bejegyzések alapján megállapított - másolási időszaka nagyon rövidnek tünik, talán ez módosítható, kitolható az adatok pontosításával. ${ }^{9}$ Balázs Mihály a kódexben ránk maradt és megjelölt, az ismert Enyedi-prédikációk

György prédikációgyüjteményének szerkezete és a prédikációk textológiai vizsgálatának tanulságai, Erdélyi Múzeum, 2013/1, 88-120; Lovas Borbála, Non multa sed multum: Párhuzamos beszédek Enyedi György prédikációgyüjteményében, Erdélyi Múzeum, 2013/1, 71-87.

${ }_{5}$ Bővebb ismertetését lásd KáLDos, Enyedi György prédikációinak, i. m., 198-201.

${ }^{6}$ A beszéd sérült, az elejéről a textus, a végéről pedig pár sor hiányzik, a könyvön belüli, a beszédet tartalmazó különálló füzetkében ma található első két lap egy lappár, amelynek hajtási oldalából van egy rész áthajtva a füzeten, tehát vagy eleve csonkán másolták le, vagy utólag pótolták részlegesen a szöveget. 7 BaLázs Mihály, A kolozsvári unitárius kollégium 262. számú kódexe = Isten és ember szolgálatában: Erdő János emlékezete, szerk. SzABó Árpád, Kolozsvár, Erdélyi Unitárius Egyház, 2007, 197-215.

${ }^{8}$ A kötés bőrborítása sérült, a felső és alsó szélen jól látszanak az egyenlő vastagságú, összefüzött füzetek. A füzetek 16 oldalasak, 4 lappárból állnak. Kivétel ez alól az első és az utolsó füzet, amelyek csak fele ekkorák. ${ }^{9}$ A datálással kapcsolatban néhány másolói megjegyzés kérdésessé teheti a megadott dátumot. Így a Balázs Mihály által példának hozott [2]. egységben az 56v-n az 1659-es évszámmal találkozunk, véleményem szerint a hasonló kontextusban szereplő másik dátum, a [6]. egységben a 109v-n, talán nem 1659, hanem 1639. Emellett a datálás árnyalásához újabb adatként egy a Balázs Mihály által [14]. egységként megjelölt, a kódex 322. oldalán kezdődő, Alius tractatus de baptismo címet viselö szövegegységben rögtön a cím alatt szereplő, a másoló kéz által beírt dátumra hívnám fel a figyelmet: C. V. Jo: D. N. 1642 Claudi. Ez a szövegrész szorosan kötődik az előzőhöz (Tractatus de baptismo), valamint azonos kéznek tünik a további lapokéval. 
között nem szereplő textusú, latin prédikáció-kivonatot és az azt követő, szintén latin nyelvü prédikációvázlatokat ismertette, mint a kötetnek a püspök életművéhez kapcsolható részét. Az adott helyről ezt írja: „[25] 457-465: Barna kéz. Latin és magyar nyelvü prédikáció-kivonatok. Az első: Idea Contionis Cl. G. Eniedi Ex Matth. 26. de urguente ephuso. További alaptextusok: Joh. 20. Joh. 2. 22. 23. ${ }^{10} \mathrm{~A}$ ránk maradt Enyedi-prédikációk között nem szerepelnek." Majd pár sorral később még egy Enyedit említô leírás következik a tanulmányban: „[27] 469-484: A barna kézzel írott prédikációk: Contio de poena neglectae occassionis Ps. 95. v. 7. 8. 477: Psa. 3. v. 10. ${ }^{11}$ Mondjátok az igazaknak, jól leszen. Enyedinél nem szerepelnek."12

Kisebb figyelmet szentelt azonban a kódex elején lévő, elég terjedelmes, hosszabbrövidebb prédikációkat tartalmazó résznek. A másoló, ahogy Balázs Mihály is megjegyzi, kezdetben az egyházi ünnepek szerint látszik rendezni a beszédeket, a rend azonban a másolás során felbomlik, vagy inkább összekeveredik. A korpuszrész egy, a vízkeresztre szánt beszéddel kezdődik, majd következik a vízkereszt utáni elsö ${ }^{13}$ és második vasárnap. Ezután néhány jelöletlen beszéd, majd kezdődnek az adventi prédikációk, karácsonyra és az utána lévő vasárnapokra szánt beszédek, újabb vízkereszti, majd a húsvéti és pünkösdi ünnepkörhöz csatlakozó darabok. Ennek ellenére a kötetrész eredeti egységes voltát támasztja alá a lapok számozása is. A régi, laponkénti számozás 1-120-ig tart, és ez után az egység után nem sokkal megszakad. Ez a körülbelül ötszáz oldalas kódex mintegy felét teszi ki. A beszédválogatás kevés eltérést mutat a kor megszokott tematikájához viszonyítva, a másoló ${ }^{14}$ a zsoltárokon kívül csak újszövetségi helyekről választ textust, túlsúlyban vannak a Máté és Lukács könyvére épülő darabok. Valószínűleg előzetes terv alapján valóban követni akarta az ünneprendet, ám később a már bemásolt beszédek közé újabbakat írt be, vagy összekapcsolt néhányat valamilyen szisztéma szerint. Ha a betoldások nem fértek be a tervezett helyre, szétbontotta azokat rövidebb részekre, melyeket később megszámozott, jelezve a többi rész helyét a cím mellett elhelyezett jegyzettel és a kapcsolódó lapszámok megadá-

\footnotetext{
${ }^{10}$ A második hivatkozás helyesen: Joh. 20, 22-23. (A jelzés a Joh. 20-hoz tartozó második beszéd elején található: Contio 2. v. 22. 23. / Et cum hoc dixisset insufflavit et dixit eis.)

${ }^{11}$ Helyesen: Esa. 3. v. 10.

12 BALÁzs, i. m., 203. Káldos János ezen ismertetést vette át fentebb már idézett cikkében: „A kódex a mostani szempontunkból is fontos, mivel a 457-465. oldalán egy Enyedi-beszéd vázlata található: Idea Concionis Cl. G. Eniedi Ex Matth. 26. de urguente ephuso. Lehetséges, hogy a 27. tétel (p. 469-484.) alatti prédikációk is Enyedi beszédeiből valók: Ps. 95. v. 7-8. (Contio de poena neglectae occassionis) és Ps. 3. v. 10. (Mondjátok az igaznak, jó lészen). Balázs Mihály ugyan megállapítja, hogy egyik textus sem szerepel Enyedi ismert beszédei között, de lehetséges az is, hogy a teljes egészében hiányzó ötödik Triacasból való néhány kivonat." KáLDos, Enyedi György prédikációinak, i. m., 201.

${ }^{13}$ Itt eredetileg egy advent 3. vasárnapjára szánt beszéd címét és textusát kezdi el beírni a másoló, amit aztán kihúz. Ez a beszéd később a 66. oldalra kerül.

${ }^{14}$ A kezet meghatározni talán nem egyszerü, mégis hajlok arra, hogy egynek tartsam. Megfigyelhető, hogyan változtatja az írásképet attól függően, hogy mennyi helye van vagy marad a szöveg bemásolására, befejezésére, néhol nyugodtan, néhol kuszán, sürün ír, valószínűleg különböző írószerszámokkal.
} 
sával; vagy az egyes textus alapján összekapcsolódó részeket később összekötötte. Azokat a darabokat pedig, amelyek a részekből álló beszédek közé estek, és ott teljes hoszszukban szerepeltek, egyes esetekben a Contio integra felirattal látta el. Vagy az eredeti másoló, vagy egy másik kéz később újrarendezte, átírta ezeket a számozásokat. Ez a kéz bele is nyúlt a szövegbe, javított, átírt szavakat, mondatokat, kihúzott szövegrészeket, átrendezett bekezdéseket, néhol sürün megjegyzetelte a margókat. ${ }^{15}$

A szövegkorpusz érdekessége, hogy néhány e prédikációk közül beazonosítható Enyedi-beszéd. ${ }^{16}$ A Mt 11, 2 textussal kezdődő és a Jn 2, 1 textusra épülő beszédek a vízkereszt utáni első és második vasárnap hangozhattak el. A Mt 2, 16-ra épülő prédikáció szintén valószínüleg olyan Heródes-beszéd, mely vízkeresztre, vagy az azutáni első vagy második vasárnapra készült. Ezt a három beszédet az 5. Kolozsvári Kódex (K5) is tartalmazza, ezek közül az első kettőt a Székelykeresztúri Kódexben (Sz) is megtaláljuk. A beszédek száma az Enyedi-korpusz számozása szerint 185., 191. és 188., vagyis a 6. triacas darabjai. ${ }^{17}$ A negyedik beazonosíthatóan a gyüjteménybe tartozó szöveg a Róm 8, 11-re épül, ezt a 2. Kolozsvári Kódexben (K2) ${ }^{18}$ találjuk meg. ${ }^{19} \mathrm{Az}$ összehasonlító elemzések szempontjából fontos, hogy az Enyedi-beszédekben is találunk példát a fentebb már említett szerkesztésre. Vagyis nem csupán a variánsok közötti eltérések figyelhetők meg a szövegekben, hanem a használó, másoló konkrét alakító munkája is.

A CV-ben található beszédekre jellemző, hogy rövidek, sok kihagyás van bennük a többi variánshoz képest, valószínűleg tudatos rövidítésről lehet szó. Az is behatárolható, hogy általában milyen részek kerülnek kihagyásra. Ilyenek a latin és görög nyelvü idézetek, a halmozott magyarázatok, a példák, a háromságosok ellen irányuló túlságosan erős kritikai észrevételek, a híveknek szóló erősebb hangú kritikák, a bonyolultabb gondolatmenetek vagy azoknak jelentős része. A továbbiakban röviden bemutatom az érintett beszédeket, néhány példával illusztrálva a $\mathrm{CV}$, valamint a többi másolat jellegét és eltéréseit.

A Máté 11,2-n alapuló 185. prédikáció indító gondolata a jó és rossz tanító, valamint a jó és hamis tudomány megítélését taglalja. A jó tanító példájaként az Ưjszö-

\footnotetext{
${ }^{15}$ A kódex elejének felépítését lásd az I. számú mellékletben.

${ }_{16}$ Az I. számú mellékletben (Conciones vetustissimae: a magyar nyelvü prédikációmásolatok textusai és szerkezeti felépítése) a [13]., [20]., [34]., [76]. oldalakon szereplő beszédek.

${ }_{17}$ Az említett beszédek pontos adatai és lelőhelyei: Mt 11, 2 - De Joanne Baptista (185. beszéd, K5, 87v-94v; 185. beszéd, Sz, 470-485; 185. beszéd, CV, 13-21); Mt 2, 16-18 - Crudelitas Herodis et Tyrannorum (188. beszéd, K5, 108v-113v; 188. beszéd, CV, 76-81); Jn 2, 1 - De nuptiis in Cana Galilaea (191. beszéd, K5, 123v-130v; 191. beszéd, Sz, 501-517; 191. beszéd, CV, 20-26).

${ }_{18}$ A beszéd pontos adatai és lelőhelyei: Róm 8-11. - De resurrectionis Christi causa (20. beszéd, K2, 193-203; 20. beszéd, CV, 34-43). A beszédek elejének összevetését lásd a II. számú mellékletben.

${ }_{19}$ A kódexeket keletkezési idejük alapján vizsgálva kitűnik, hogy a másolási időszakok nagyrészt egybeestek. A legkorábbi a válogatott tartalmú Sz, 1629-re datálva. A CV ismertetett másolási időszakával talán egy időben készült el emellett a K5, melyet pontos adatok híján a 17. század közepére szokás datálni. Legkésőbbi másolatnak a K2-t tarthatjuk, melynek befejezési dátuma 1664. Vagyis nem egymástól időben távol eső másolatokról van szó. Ez még látványosabbá teszi az aktív másolási hagyomány sokszínűségét.
} 
vetség „két fő vezér”-e, Keresztelő Szent János és Jézus szolgál. ${ }^{20}$ A szöveg - amellett, hogy kemény kritikával illeti a rossz uralkodókat, Heródes tetteit és egyéb példákat elővéve - azt is világosan bemutatja, hogy a tanítóknak el kell viselniük a megpróbáltatásokat, rabságot, sokszor a halált is. Ez, bár minden időben tanulságos témaként forgott a prédikátorok tollán, az 1590-es évekbeli erdélyi unitárius állapotokat figyelembe véve talán többet mondhatott a híveknek, mint első olvasatra gondolhatjuk. Bár a CV másolója erősen meghúzta a szöveg ezen részét is, a K5-ben nem csupán az alapkoncepció, de annak bővebb kifejtése is olvasható. Szolgáljon az ez utóbbiból idézett néhány példarész az elmondottak alátámasztására:

Erre azért nézvén Szent János, megfeddé Heródest, de az igazmondásért (amint szokott lenni) betörék a feje, tömlöcre vetteték, és végre ugyanott megöleték. Nem különben vagyon azért a tanítóknak dolguk, mint akik azt mondják: Előttem víz, utánam tüz. Ha hallgatnak, elöttük az Istennek kemény parancsolatja, haragja és büntetése. Ha szólnak, ez világi hatalmasoknak fogságukba és üldözésükbe esnek. Nem csak Szent Jánosnak volt pedig így dolga, hanem inkább minden jámbor tanítóknak, prófétáknak, mind ő előtte s mind ő utána ez volt virága ilyen jutalma és fizetése ez háládatlan világtól. ${ }^{21}$

Majd az alapgondolatra példasort épít a püspök:

Ekképpen jára Mikeás, mikor igazat prófétála Acháznak, megnyaggaták, és kemény tömlöcbe veték. Zakariás a Jójáda pap fia kővel agyonvereték, Ézsaiás fürészszel metszeték ketté. Jeremiás az undok halálos tömlöcbe rekeszteték, Uriás próféta Jer. 26. levágaték. Krisztus felfeszítteték; Szent István megkövezteték; Szent Jakabnak feje veteték, Szent Péter megfogaték; sőt ugyan majd nem volt egy igaz próféta és apostol is, aki szörnyü és kegyetlen halállal ne múlt volna ki e világból. ${ }^{22}$

Majd miután elmondja és citátumokkal alátámasztja, hogy Jeruzsálem városa eláradt az ártatlanok vérével, ${ }^{23}$ így foglalja össze e rész tanulságait:

\footnotetext{
${ }^{20}$ Míg a CV-ben ez a beszéd önmagában áll, K5-ben és Sz-ben ezt követi a 186. beszéd, Mt 11, 7 textussal. A beszédek összetartozását erősíti a bibliai helyre való utalás Ibidem 7. rövidítése, valamint a beszédekbe illesztett visszautalások. „Mondám azért ezt tegnap is, hogy az Evangéliumban az Újtestamentumnak két fö vezérinek böcsületes személyek íratik meg.” (K5, 95r); „Mondám az elmúlt prédikációmban is, hogy az Evangéliumban és az Ujtestamentumnak két fö vezérének böcsületes személyek íratik meg." (Sz, 486.)

${ }^{21} \mathrm{~K} 5,88 \mathrm{v}$.

${ }^{22} \mathrm{~K} 5,89 \mathrm{r}$.

${ }^{23}$ Nem haszontalan ezen a ponton a zsidó-magyar párhuzamot erősítő Enyedi-beszédekre gondolnunk, melyek - sok kortárshoz hasonlóan - Erdélyt az új Jeruzsálemmel azonosítják. Ebben a kontextusban a példasor még inkább aktualizálttá válik. Lásd például: „Bizony, hogy nem sokkal különb állapotban vagyunk, mint akkor valának az zsidók. Sennacherib elpusztította vala Júda országát, minden
} 
Itt pedig két tanulság vagyon: Egyik néz a tanítókra, hogy tudniillik, noha minden felől veszély rajtuk, de inkább akarjanak az embereknek, hogynem az Istennek haragjába esni, és vigasztalják magukat a sok régi előttük való szentek és próféták példájával. Ilyen háládatlan volt minden kor és világ, így fizetett az ő jámbor lelkipásztorainak. De azt mondja Krisztus Urunk, hogy nem azoktól kell félnünk, akik a testet megölik, azután nem tudnak mit tenni, hanem attól, aki mind testestől-lelkestől a Gyehennának tüzére vethet. Második tanulság néz a hallgatókra, hogy a tudományt ne ítéljék a nyomorult tanítónak állapotjáról, és szidalmas, gyalázatos haláláról. ${ }^{24}$

Ezután: „Az igazságnak mindenkor több ellenségi vannak, hogynem patrónusi voltak volna. Sőt, ez világ elött való kedves tudományhoz mindenkor gyanakodjál, mert az gyakrabban hamis." ${ }^{25}$ A prédikáció szövegében a CV-beli változatban máshol is hosszabb-rövidebb kihagyások vannak a K5-höz képest, a leghosszabb egy körülbelül 150 sornyi rész, mely hosszasan taglalja azt, hogy Keresztelő Szent János és Jézus ismerhették-e egymást, majd hogy János miért küldte tanítványait Jézushoz, és erről mit tartanak a kárhoztatandó háromságos vélekedések. A kihagyott szöveghely nem csupán azért érdekes, mert a K5 Jacobus Palaeologusra is hivatkozik benne, ${ }^{26}$ de azért is, mert gondolatvezetésének módja arra enged következtetni, hogy a rész eredetileg is szerepelt a beszédben, és nem a kolozsvári kódex másolójának túlburjánzó magyarázatáról van szó. Emellett, bár a K5 szövege megegyezik ezen a helyen Sz változatával, utóbbiból kimarad a megjegyzés. Hasonlóan nem szerepel a K5-ön kívül egyik variánsban sem az az Erasmusra való, a folyószövegbe írt utalás, mely a galamb képében Krisztusra szálló Szentlélek mint Szent János számára világos jel említése után következik. ${ }^{27}$ Általánosságban elmondható emellett a K5-röl, hogy margói sürün jegyzeteltek, hivatkozásai jelöltek, a másoló sokszor külön kiemelte, vagy kiegészítette azokat. A CV-ben (és az Sz-ben) sokkal kevesebb a forrásokra való utalás, a jegyzetek pedig elhanyagolható számúak. Azonban míg az Sz a beszéd hosszabb változatát hozza, a CV sok kihagyással él. A rövidített változat is tartja a beszéd struktúráját, s bár nem olyan olvasmányos és kevesebb példával él, követi a bővebb változatot.

erös várakat megvett vala, csak Jeruzsálemben szorultak vala az zsidók, az kik megmaradhattak vala. Nem úgy vagyon-e dolgunk nekünk is? Az pogány török Magyarországnak minden városit, várait megvette, elfoglalta, az mi kevesen maradtak az szegény magyarok, mint egy Jeruzsálemben, ide Erdélyben szorultanak [...]." (114. beszéd, S, 164-165.)

${ }^{24} \mathrm{~K} 5,89 \mathrm{r}$.

${ }^{25}$ Uo. Későbbi, valószínűleg 20. századi margójegyzet az utolsó előtti idézet alatt: Dávid F +. A CV-ben a próféták halálának példasora után ez a rész kimarad.

${ }^{26}$ K5, 92v: „Palaeologus ait Baptistam sciuisse quod Jesus esset Messias Judaeorum, sed percontatum de novo Regno, et titulo an scilicet esset etiam Rex proputiatoris et gentium, hoc enim significabatur per eum qui venturus dicebatur."

${ }^{27}$ K5, 91v: „(Postea deprehendi de hoc loco disputationem Erasmi, quam vide.)” 
A kánai menyegzőről szóló, a Jn 2, 1-en alapuló beszéd, melynek vizsgálata kapcsán találtam rá az Enyedi-beszédekre, a korszak egyéb beszédeihez hasonlóan igen erős kritikával él a házasságellenes tendenciákkal kapcsolatban. Mindhárom variáns tartalmazza ezt a - itt a K5-ből idézett - részt: „Honnat mi legelőbb tanuljuk meg, hogy noha voltak oly féle nemzetségek, az mint az pogányok írásában olvassuk, kik az házasságban semmi jó, és dicséretes rendtartást nem követtenek, és még az filozófusok közül is voltak, kik az közönséges és oktalan állatok módja szerint való társalkodást is vallották, kikhez majd hasonló tudományt akartak ez elmúlt nem sok esztendőkben némely Anabaptisták az kereszténységbe hozni. De mindazonáltal az régi szenteknek példái és históriái megmutatják, hogy az Istennek ez tisztességes rendelését mindenkor az hívek megbecsüllötték és abban jó módot, szép és illendő rendtartást követtenek." ${ }^{28}$ Ezt a prédikációt a CV szintén rövidíti, a leghosszabb kihagyott rész mintegy 125 sornyi. Ez a vendégeknek a lakodalomra való hívásának menetét fejti ki, és reflektál a korszak tobzódó lakodalomtartási szokásaira is, majd a katolikusok ellen szól hosszan azok ellentmondó érveléseivel kapcsolatban. A másoló szintén kihagy gunyorosnak is mondható példákat a borisszákkal és Jézus csodájának értelmezésével kapcsolatban, és nem tér ki arra, mennyi vizet is változtatott át Jézus, melynek számolgatásába nem csupán a másik két kódex másolója, de a kor prédikátorai is rendre örömmel feledkeztek bele. Azt, hogy valószínűsíthetően a beszéd eredeti változata a K5-tel megegyező hosszúságú volt, és a $\mathrm{CV}$ jelentősen lerövidítette azt, alátámasztja, hogy sok eltérés esetében a hosszabb változatot tartalmazza az Sz variánsa is. Lássunk erre egy érdekes példát, mely a közkedvelt méh-hasonlat egy változatán keresztül világít rá arra, hogyan értelmezik félre a menyegzőn elfogyasztott bor mennyiségét a rosszlelkü olvasók.

\footnotetext{
${ }^{28} \mathrm{~K} 5,124 \mathrm{r}$.

${ }^{29}$ „Másodszor itt szükség, hogy némely Isten ellen termett trágár emberek beszédéről szóljak, kik így szoktak néha csúfolkodni és az Istennek sz. beszédével játszadozni, és az ő gonoszságoknak palástot, színt kerítni. Látod-e, meg tetszik, úgymond, hogy az menyegzőben szabad jól innia és megrészegedni, mert abban az lakodalomban úgy meg írták, hogy még borok is el fogyott. Ez ilyeneknek először azt kel mondani, hogy ha az sz. Írást oly igen böcsülik, hogy onnat akarnak regulát, rendet életükre vonni, hogy nem ment eszekben ezeknek, mennyi helyen ő neki sok példákkal kárhoztatja az írás az tobzódást és az részegséget. Bizony, te is annyi mondást és Parancsolatot találsz az Szentírásban az tobzódás ellen, hogynem ahol út nyittatnék az bor italra. De ezek szintén olyanok, mint az legyek, Nem olyanak mint az méhek. Az méhnek ilyen természeti vagyon, Hogy mikor mérges füre száll is, édes mézet szív és vonszon ki belöle. De az légy olyan, hogy még az ép testet is megsebesíti, és ahol valami kis vakarítást talál, addig szíja, marja, hogy túrós sebet csinál belőle. Ezféle tobzódók is olyanok, hogy az szentírásbeli jó példákat is gonoszra magyarázzák, és abból valami kis alkolmatosságot kaphatnak az ő gonoszságoknak el fedezésére, azt mind addig piszkálják, hogy undok sebet csinálnak belőle. De itt bizony ezféléknek semmi palástjuk nincs, Mert úgy vagyon, hogy az tisztességes vigasság, mikor jelen és módjával vagyon, Nem kárhoztatandó, De az felettük való tobzódás mindenütt tilalmas. Hogy pedig ez lakodalomba el fogyott az bor, nem ez vala az oka, hogy igen ittak, hanem hogy szegény volt a gazda. És az Isten akaratja volt, hogy eképpen Krisztus Urunknak alkalmatosság adassék az csudatételre." (Sz, 510-511.)
} 
CV (22)

Másodszor szükség, hogy itt valami trágár ember beszédéről szóljak, kik így szoktak néha csúfolkodni, és az Istennek szent beszédével játszani.

Megtetszik, úgymond, hogy az menyegzőben szabad jól innia, és megrészegedni, mert abban az lakodalomban úgy ittak, hogy még boruk is elfogyott.

Hogy pedig ebben az lakodalomban elfogyott volt az bor, nem az volt az oka, hogy igen ittak, hanem hogy szegény volt az gazda, és az Isten akaratja, hogy így Krisztus Urunknak adassék alkalmatosság az csudatételre.

\section{K5 (127r $)^{29}$}

Másodszor itt szükség, hogy valami trágár emberek beszédéről szóljak, kik így szoktak néha csúfolkodni, és az Istennek szent beszédével játszadozni, és az ő gonoszságuknak palástot keresni.

Megtetszik úgymond, hogy az menyegzőben szabad jól innia, és megrészegedni, mert abban az Cana Galileabeli lakodalomban úgy ittak, hogy még boruk is elfogyott;

Ez ilyeneknek először azt kell mondani, hogy ha az szentírást oly igen becsülik, hogy onnét akarnak regulát rossz életükre venni, hogy nem jut eszükbe, mennyi helyen, és mely sok példákkal kárhoztatja az írás az tobzódást, és részegséget. Bizony, tízannyi mondást és parancsolatot talál az szentírásban az tobzódás ellen, hogy nem ahol út nyittatnék az boritalra. De ezek szinte olyanok, mint az legyek, nem olyanok, mint az méhek. Az méhnek ilyen természete vagyon, hogy mikor mérges füre száll is, édes mézet szív ki belőle; de az légy olyan, hogy még az ép testet is megsebesíti, és ahol valami kis szakadást talál, addig szívja, marja, hogy túrt, sebet csinál belöle. Ezek is az szentírásbeli jó példákat is gonoszra magyarázzák, és ha valahol valami kis alkalmasságot kaphatnak az ö gonoszságuk fedelére, azt addig piszkálják, vitatják, hogy undok sebet csinálnak. De itt bizony semmi palástjuk nincs. Mert úgy van, hogy az tisztességes tudomány mikor helyén és jó módjával vagyon, nem kárhoztatandó, de az felettébb való tobzódás mindenütt tilalmas.

Hogy pedig az lakodalomban elfogyott volt az bor, nem az volt az oka, hogy igen ittak, hanem szegény volt az gazda, és az Isten akarta, hogy így Krisztus Urunknak adassék alkalmatosság az csudatételre.

Egy kicsit eltér az eddigiektől a Rómaiakhoz írt levél 8, 11-hez készült prédikáció, mely a CV mellett a 2. Kolozsvári Kódex anyagában szerepel. Bár a K2 egy jól olvasható, tiszta kódexnek tünik, a szorosabb vizsgálatok azt mutatják, hogy szövege rejt még magában megoldandó filológiai problémákat. Más kódexekkel való párhuzamosságai, a beszédek utólagos számozása, a centuria- és triacas-számozás furcsaságai azt támasztják alá, hogy sokkal érdekesebben illeszkedik be a korpuszba, mint azt eddig gondoltuk. A feltámadás kérdését körüljáró beszédben csupán egy példát és egy erős kritikát tartalmazó mintegy harminc sornyi, sürü bizonyítási részt - mely Krisz- 
tus istenségének problematikáját fejtegeti - hagy ki a CV másolója a K2 szövegéhez képest. Emellett azonban a beszéd több része a CV-ben van csak meg, míg a K2-ből hiányzik. Krisztus örök istenségéről szóló téves tanítás és pontokba szedett cáfolata, Krisztus emberségének bizonyítása és bibliai citátumokkal való alátámasztása, ebből kifolyólag a test feltámadásának kérdése, és a feltámadás módja is szóba kerül a beszéd során, feszesen levezetett gondolatmenetbe illesztve.

A CV utolsó Enyedinek tulajdonítható beszéde szerkesztési szempontból tartogat leginkább újdonságokat. A 188. prédikáció egy Heródes-beszéd, kissé hátrébb található a kódexben, érdekessége azonban nem ez, hanem az, hogy egy háromrészes beszédcsokor közepére van beillesztve. ${ }^{30} \mathrm{~A}$ beszédek sorrendje a másolás során, majd később is alakult, valószínüleg eredetileg nem így kapcsolódtak egymáshoz, vagy más prédikációkhoz. Először a csokor második részével találkozunk a kötetben, majd mintegy harminc oldallal később szerepel az első rész, és ezután több mint száz oldallal a harmadik, mely textusát tekintve nem is szorosan a másik kettő folytatása. A csokorból csak a középső beazonosíthatóan Enyeditől származó prédikáció. ${ }^{31} \mathrm{~A}$ beszéd szövegét vizsgálva a CV-ben több helyen is találunk kihagyásokat, pár sorosaktól - halmozott magyarázatok, a pápa elleni kiszólás, a nagy elméjü uralkodókról személyeskedő megjegyzések, antik szerzőktől származó idézetek és forrásjelölések - hosszabbakig, mint annak magyarázata, hogy vajon azért történt Krisztus születése után két évvel a kisgyermekek legyilkolása, mert a Bölcsek nem értek rá, vagy mert Heródesnek kellett elutaznia előtte. Hosszabb példasorok is kimaradnak, így többek között mintegy ötven sornyi szöveg, ${ }^{32}$ majd egy újabb, mintegy kilencven sornyi kihagyás kicsivel később, mely antik szerzőktől vett példákat tartalmaz. A beszéd végén még mintegy húsz sornyi, bibliaértelmezési kérdéseket taglaló kihagyás van. A beszéd hangvételében több, Enyedi által kedvelt és gyakran magyarázott kulcstémához is kötődik, így egyfelől a jó és rossz uralkodó

\footnotetext{
${ }^{30}$ [76] Mt 2, 16 (Contio 2.) margójegyzete: „Vide Numero 50 ibi erit prima pars. Tertia pars [...] vide Numero 111 et illic erit.”; [107] Mt 2, 15 (Contio prima) margójegyzete: „[...] numerum 36 ibi erit 2da pars.”; [227] Mt 2, 13 (Contio 3.) margójegyzete: „Prima Co. in. Numero 50 [...] 2da pars in Numero 36 [...]”.

${ }^{31}$ A harmadik darab is összefüggésbe hozható egy apróságban az Enyedi-gyüjteménnyel. A K5 margóján egy megjegyzést találunk: „Quae haec precedent explicantur Tria. 4. Concione 123.” Ugyanígy a (ma az S kódexben fennmaradt) 123. beszéd margóján a következőt olvashatjuk: „Quae sequentur haec verba applicantur Concione 188." A CV-ben szereplő beszéd, bár textusa egyező a beidézett 123. beszéddel, szövegében nem egyezik azzal.

${ }^{32}$ Az említett rész így kezdődik: „Efféle példákat olvasunk, hallunk, és látunk, kik nem csak az idegeneket, hanem az ő atyjukfiait is, szerelmesit is megölették, levágatták, sőt az édesatyjuk magzatit. Innét kelt majd ugyan proverbiumban amaz istentelen mondás: ha az hitet meg kell szegni az birodalomért (királyságért), szegd meg, egyéb dolgokban szent és igaz hitű lehetsz. Kinek példáját ugyan csak a mi időnkben is hallottuk és értettük. Mint amaz Navarrai király dolga immár mindennel nyilván vagyon." (K5, 111v.) Az utalás IV. Henrik navarrai, majd francia királyra, a Szent Bertalan éjszakáján elkövetett mészárlásokra és a király színleg való rekatolizálására, majd a francia trón megszerzése érdekében való végleges áttérésére utal.
} 
kérdéskörét járja körül, ezúttal egy újszövetségi példa kapcsán, ${ }^{33}$ másfelől az igazság és az igaz tudomány hirdetésének nehézségei és ellenségei kerülnek újra elő.

Az eltérések, rövidítések ellenére elmondhatjuk, hogy a CV-ben szereplő beszédek az eredeti struktúrát tartják, kissé szűkszavú, de feszes, lényegre törő szöveget adnak. A prédikációk és a másolásokban eszközölt változtatások további vizsgálata érdekes részleteket tárhat fel a szöveghagyományozódás és a korabeli beszédszerkesztési gyakorlat kérdéseivel kapcsolatban. És természetesen újra fel kell tennünk a kérdést: mit tekintünk Enyedi György prédikációinak?

\section{Melléklet I. ${ }^{34}$}

Conciones vetustissimae: a magyar nyelvü prédikációmásolatok textusai és szerkezeti felépítése

[9] Mt 2, 1

[13] <Lk 7, 17-20 (Dominica 3. Advent) $>$.

[13] Mt 11, 2

[20] Jn 2, 1

[26] Lk 2, 25

[34] Róm 8, 11

[43] Zsolt 33(34), 16

[45] Zsolt 33(34), 12

[48] Zsolt 14(15), 1

[52] Lk 21, 25 (Dominica 2da Adventus)

[56] Lk 21, 34 (Contio 2da ex eodem capite)

[59] Mt 24, 30 (Contio integra)

[64] Mt 13, 41 (Contio <quarta>)

[66] Lk 7, 17-20 (Dominica 3. Advent)

[69] Lk 7, 24 (Contio secunda ex eodem cap.)

[72] Lk 7, 28 (Contio 3. ex eodem cap.)

[74] Mt 11, 13 (Contio <quarta> Luca 16.)

[76] Mt 2, 16 (Contio 2.)

[81] De matrimonio

[85] Mt 21, 1 (Dominica Advent)

[90] Jn 1, 9 (Dominica Advent 4.)

[94] Jn 1, 25 (Contio 2 Ex eodem)

\footnotetext{
${ }^{33}$ Nem nehéz olyan utalásokat találnunk, melyeket könnyedén a fiatal fejedelemre vonatkoztathatunk, még ha a párhuzam nincs is kimondva. Egy érdekes példa álljon itt a számtalan közül: „Ezekből mi elsőben tanuljuk meg, az harag, mely sok gonoszságra és méltatlan kegyetlenségre viszi az embert, hogy néha másra haragszik meg, és máson tölti ki bosszúját. Mint ez Heródes a Mágusokra haragvék meg, és a Bethlehembeli ártatlan gyermekecskéken tölté ki bosszúját, azokra önté ki haragját. Nem különben mint az gyevere [új eb - L. B.], mikor az emberre ugat, arra haragszik, ha valami kővel vagy fával megütik oldalát, azt rágja harapja marja, mintha az volna bűnös. Azért óvjuk magunkat a haragtól, nem jó tanácsadó, és olyra viszen, ami nem méltó." K5, 111r-111v. 34 [Szögletes zárójelben] az oldalszámokat tüntetem fel, az oldalszámoknál a későbbi számozást követem. A beszédek textusait az egységesített jelölés szerint hozom. Zárójelben az ünnepet, ha jelölve van a címben, a több részből álló beszédeknél a beszéd jelölését, az egyéni beszédeknél a Contio integra jelzést tüntetem fel. <Csúcsos zárójellel> a javított, kihúzott részeket jelölöm. A bemutatott lista célja, hogy érzékeltesse a szövegegység bonyolult felépítését.
} 
[96] Jn 1, 29 (Contio 3. Ibidem)

[97] Mt 1, 18 (Ad Diem Nativitatis Christi)

[103] Mt 1, 20 (Contio 2da)

[107] Mt 2, 15 (Contio prima)

[108] ApCsel 7, 55 (Contio 4ta)

[112] Gal 3, 23

[115] Lk 2, 45 (Contio 3.)

[118] Lk 2, 39 (Contio 4.)

[119] Mt 2, 1; (Dominica 2. post Nativitatem Christi)

[123] Lk 8, 8 (Contio Alia)

[125] Lk 8, 9 (Contio ex Eodem)

[128] < Mt 13> Lk 18, 31 (Dominica Quinquagesimae, Contio quarta)

[132] Lk 18, 34 (Contio 3.)

[134] Mt 8, 22 (Contio < quarta> Tertia)

[137] Lk 2, 46 (Contio 2. ex eodem)

[139] Lk 2, 47-48 (Contio 3tia)

[141] Lk 2, 50 (Contio quarta)

[143] Jn 2, 1 (Dominica 4. Post Nativitatem)

[148] Jn 2, 1 (Contio 2da)

[150] Lk 4, 16 (Contio Prima <3tia>)

[152] Lk 4, 16 (Contio 2. Ex eodem loco)

[155] Mt 8, 1 (Dominica 5ta, Contio Prima)

[163] Lk 4, 31 (Contio 3ia)

[165] Mt 8, 5 (Contio <3tia > 2da)

[169] Mt 8, 23 (Dominica sexta, Integra Contio)

[174] Jn 5, 36 (Contio 2.)

[176] Mt 8, 28 (Contio Quarta)

[179] Mt 13, 24 (Dominica septima)

[183] Mt 13, 26 (Contio secunda ex eodem capite)

[185] Mt 13, 39 (Contio Tertia ex eodem capite)

[187] Mt 13, 29 (Contio quarta Ex eodem capite)

[188] Mt 20, 1 (Dominica Septimagesima)

[193] Mt 4, 1 (Dominica <Invocavit> I. Quadragesima)

[198] Mt 4, 2 (Contio Secunda ex eodem capite)

[201] Mt 20, 16 (Contio 1.)

[203] Mt 20, 16 (Contio 2da)

[204] Lk 8, 4 (Dominica Sexagesima, Integra Contio)

[210] Mt 13, 10 (Contio quarta)

[215] Tit 2, 11 (Contio <Quinta>)

[216] Lk 2, 1 (Dominica prima Post Nativitatem)

[221] Lk 2, 15 (Contio Secunda)

[223] Lk 2, 21 (Die Circumcisionis, Integra Contio)

[227] Mt 2, 13 (Contio 3.)

[229] Mt 2, 16 (Contio 1. alio Methodo)

[231] Mt 2, 19 (Con. <4.> 2. alio Methodo)

[233] Lk 2, 42 (Dominica 3. post Nativitatem)

[236] Lk 2, 18 (Contio <3> 2.)

[240] Lk 19, 1 (Contio 4ta)

[243] Mt 4, 5 (Contio 3ertia) 
Melléklet II.

20. beszéd eleje

$\mathrm{CV}$

Contio ad Romanos cap. VIII.

Hogy ha annak lelke, az ki feltámasztotta halottaiból az Jézust, lakik tibennetek, [...]

Nem ok nélkül mondta volt az apostol Col. 2., hogy az Krisztusban minden bölcsességnek és tudománynak kincsei el vannak rejtve, mert ha ki Krisztus Urunk életének folyását, beszédét és cselekedeteit minduntalan elméjében forgatja és állapotjáról szorgalmatosan gondoskodik, nem csak az itt való tisztjét és hivatalját, mint egy tükörből megláthatja és tanulhatja. De az következendö életben való állapotja felöl is bizonyos lehet, úgy, mint kiben immár mindenek beteljesedtenek, eltökéllettettenek, és mint egy kincset, ábrázatban formáltattak.

\section{K2}

Concio. Rom. 8.v. 11. De Resurrectionis Christi causa. Hogy ha annak lelke, az ki feltámasztotta halottaiból az Jézust, lakik tibennetek etc.

Nem ok nélkül mondta az apostol Col. 2., hogy az Krisztusban minden bölcsességnek és tudománynak kincse el vannak rejtve. Mert ha ki Urunk életének folyását, beszédét és cselekedetit minduntalan elméjében forgatja és állapotjáról szorgalmatosan gondolkodik, nemcsak az itt való tisztit és hivatalját, mint egy tükörben megláthatja és tanulhatja, de az következendö életben való állapotja felöl is bizonyos lehet, úgy, mint kiben immár mindenek beteljesedtenek és mint egy kimetszett ábrázatban kiformáltattanak.

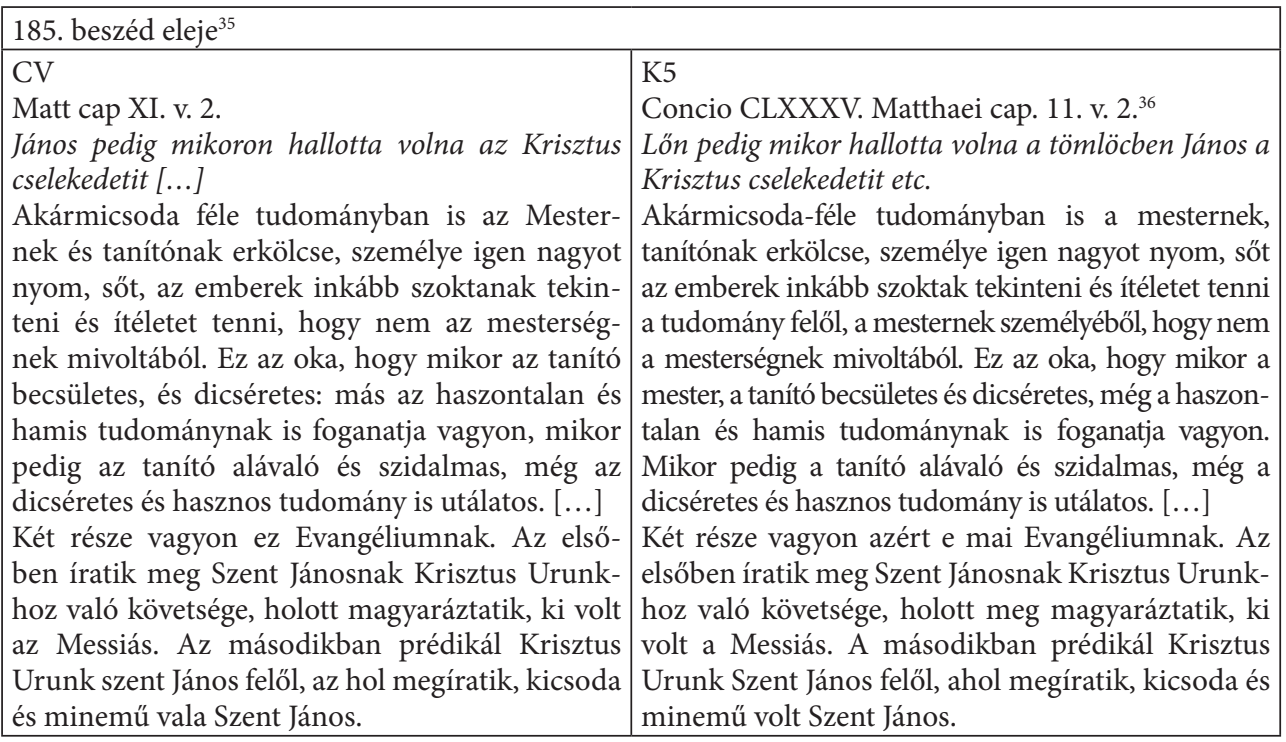

\footnotetext{
${ }^{35}$ Margójegyzet: De Nuptiis in Cana Galileae celebratis.

36 Sz: „Concio / Joannis Cap II. / És harmad napon menyegző lőn Chana Galileában, és ott vala az Jézusnak anyja is. [...] Mikor az E.M.F. Úr Isten az ő nagyságos dolgainak véghezvitelére valami erőtelen és alávaló rendből választ embereket, csudatételek által szokta azoknak az ő hivataljukat megbizonyítani, hogy se ő maguk, se egyebek felől nem kételkedhessenek. Mivelhogy annak okáért az király méltóságra választá igen alávaló rendből és nyomorult állapotból az Jézust, csudatételekre való hatalmat ada neki, hogy az emberek az ő méltósága és dicsősége felől megbizonyosodnának, és elhinnék, hogy ő legyen az igaz messiás. Azokat pedig, az csudákat, kikkel hivatalját és méltóságát megbizonyítja, noha az evangélisták nem mind írták meg, de azért nagyobb részét és fejét fejét írva hagyták, az kik közül egyik, sőt az mint itt olvassuk, legelöl vagyon megírva ez mostani előszámlált igékben. Melynek megírásában az evangélista ilyen rendet követ. Elsőben szól az menyegzői lakodalom felöl. Másodszor ott az menyegzőben, Krisztus urunktól lött csudának minden rendit és módját megírja. Harmadszor az csudatételnek okát és hasznát megjelenti. Mely módot és rendet mi is kövessünk tanításunkban."
} 


\begin{tabular}{|l|l|}
\hline \multicolumn{2}{|l|}{ 188. beszéd eleje } \\
\hline CV & K5 \\
Contio 2. Matti. 2. v. 16. & Concio CLXXXVIII. Matt. cap. 2. v. 16, 17, 18. ${ }^{37}$ \\
Akkoron látván Heródes, hogy megcsúfoltatott volna & Akkor látván Heródes, hogy megcsúfoltatott volna \\
az mágusoktól, ezen felgerjede [...] & az Mágusoktól, igen megharagvék etc. \\
Mely nagy ellenségelegyen ezaz világ az igazságnak, & Mely nagy ellensége legyen ez a világ az igazság- \\
és az igaz tudomány hirdetőinek, noha sok egyéb & nak és az igaz tudomány hirdetőinek, noha sok \\
példákból is nyilván van, de fóképpen az mi fejünk- & egyéb példákból is nyilván vagyon: de főképp az mi \\
nek, az Úr Jézus életének históriája megmutatja, ki & fejünknek az Úr Jézusnak példája megmutatja, ki \\
nem csak tanításakor és tisztiben való eljárásakor, & nem csak tanításakor, és tisztiben való eljárásakor, \\
hanem megszületése és gyermekségekor is ez világi & hanem megszületése és gyermekségekor is ez világi \\
kegyetlenektől háborgattatott és üldöztetett. [...] & kegyetlenektől háborgattatott és üldöztetett. [...] \\
Vagyon pedig ez igéknek három részei, mert elsö- & Vagyon pedig ez igéknek 3 részük. Mert elsőben \\
ben íratik meg Heródesnek kevélysége, másod- & íratik meg Heródesnek kevélysége, másodszor \\
szor szörnyủ kegyetlensége, harmadszor egy régi & szörnyü kegyetlensége. Harmadszor régi próféciá- \\
próféciának megmagyarázása, beteljesedése, és az & nak megmagyarázása, beteljesítése és az akkor lett \\
két dologhoz alkalmaztatása. & dologhoz alkalmaztatása. \\
\hline
\end{tabular}

${ }^{37}$ Margójegyzet: Crudelitas Herodis et Tyrannorum.

${ }^{38}$ Margójegyzet: De Joanne Baptista. Tractavi in Czokfalva 1673.

39 Sz: „Concio Matt. cap. XI. v. 2. / János pedig mikor hallotta volna a tömlöcben a Krisztusnak cselekedetit, [...] Nem csak a példaadásért, hanem a tudománynak becsületéért íratnak meg a fö embereknek személyük és életük. Mert akárki is nagyobbnak tartja és igazabbnak hiszi azt, az mi méltóságos, dicséretes embertől származik. Mondám az elmúlt tanításban is azért, hogy az Evangéliumban is az van. Akármicsoda tudom, amiben is a mesternek és a tanítónak erkölcse és személye igen nagyot nyom: Sőt, az emberek inkább szoktak tekinteni és ítéletet tenni valamely tudomány felöl, a mesternek személyéből, hogy nem a tudománynak mi voltából. Ez az oka, hogy mikor a mester, a tanító becsületes, és dicséretes, még a haszontalan és hamis tudománynak is foganatja vagyon. Mikor pedig a tanító alávaló és szidalmas, még a dicséretes, hasznos tudomány is megvetett és utálatos. [...] Két része vagyon azért ez mai Evangéliumnak. Az elsőben íratik meg Szent Jánosnak Krisztus Urunkhoz való követsége. Holott megmagyaráztatik, ki volt az Messiás. Az másodikban prédikál Krisztus Urunk Szent János felöl. Ahol megíratik, kicsoda és minemü volt Szent János.” 


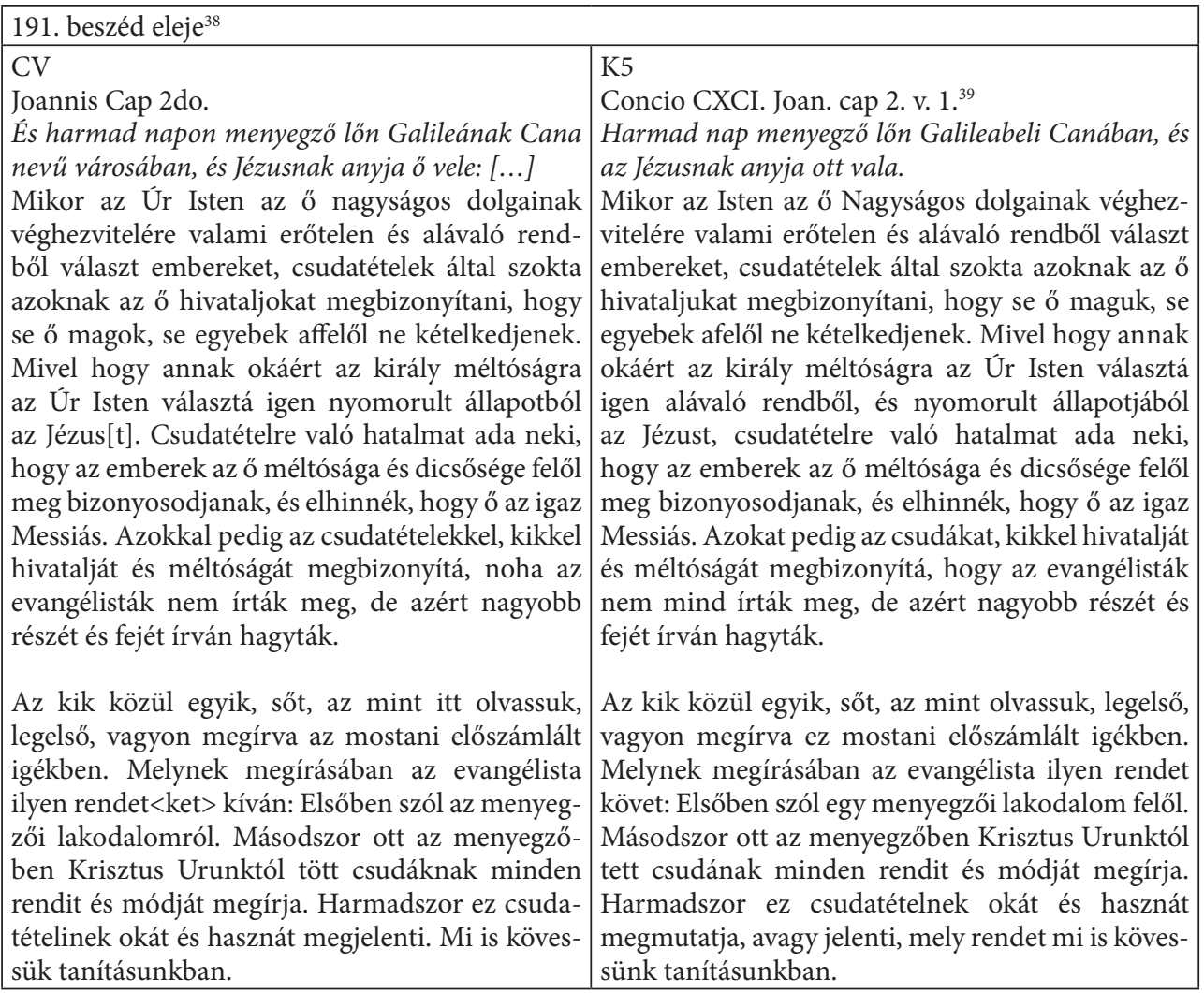

\section{BORBÁla LOVAS \\ Copying Strategies in the Textual Tradition of György Enyedis Sermons}

The sermon collection of György Enyedi (1555-1597), the third bishop of the Unitarian Church, is an especially large corpus representing a unique handwritten textual tradition. During the almost one hundred years of active copying, a large amount of its variants were issued. Today we mostly know copies of triacases (thirty or thirty-three sermons in one block) or selected sermons in mixed collections. They can be easily identified by the copyists' or users' notes. Also, even if there are damages and disorders in the structure, the beginning and the ending of the texts - without taking notice of the regular variability of synonyms or word order - are comparable and can help in identifying unnumbered and unmarked texts. In my paper I wish to introduce four new sermon variants. They can be found in Contiones vetustissimae (Romania, Cluj Napoca, Academia III., MS.U. 262.), a Unitarian codex with mixed 
content. Until now the first part of it, a collection of sermons in Hungarian language mostly shortened and often edited - has been ignored. This part contains the bishop's four sermons without identification signs. The closer examination of these new variants, in comparison with other versions can help us to understand the strategies of the copyists. Also, we can examine more precisely why and how the textual details of these sermons remained the same or changed in any way during the 17th century. 